\title{
TRANSITIONAL JUSTICE BETWEEN RETRIBUTIVE AND RESTORATIVE JUSTICE
}

\author{
Oliver Bačanovikj \\ Faculty for Security, St. Kliment Ohridski University \\ bacanovicoliver@gmail.com
}

\begin{abstract}
The text aims at defining the concept, the elements and the relationship between restorative and retributive justice in the context of transitional justice. The basic hypothesis is that the goals of transitional justice are broader than those of the retributive justice, or better - it is a more complex phenomenon that cannot be reduced to criminal charges and trials. It corresponds to the nature of the societies in transition from authoritarian regimes and/or post-conflict societies that face challenges, such as: providing satisfaction of the victim, active engagement of all the participants in the restorative process (i.e. the perpetrator, the victim, and the community), reform of the institutions as well as the system as a whole, and finally -reconciliation as a precondition for the achievement of the final goal i.e. enduring peace. All this requires performing complex and long-term activities, but provides for a final and significant result - the reconstruction of the society through the rule of the law, democracy and the respect of human rights and freedoms.
\end{abstract}

Key words: transitional justice, restorative justice, retributive justice, post-conflict societies, post-authoritarian societies.

Introduction

Those who do not remember the past are doomed to repeat it. George Santayana

In the second half of the $20^{\text {th }}$ century, particularly from the 1970 s onwards, the world witnessed a raise of numerous intra-state conflicts. There were mass abuses of human rights; ${ }^{1}$ and by default they were a result of the armed violence or the terror of the

\footnotetext{
${ }^{1}$ Although every context is unique, post-authoritarian or post-conflict transitions have one thing in common, which is precisely the legacy of mass violations of the human rights. This refers to the
} 
authorities (in the authoritarian regimes). Mass violations of human rights and war crimes have been taking place before, during, or after the fall of the regimes or even the end of armed hostilities between the conflict parties. A key feature of these developments is the mass violation of human rights ${ }^{2}$ that was taking place among people who used to live together as family-members or members of the same communities in close relationships. Normalization of life in the post-conflict period not only called for establishing so-called traditional or retributive justice but also for re-establishment of the societal relationships for the sake of the present generations of people, and even more - for the future ones. According to the transitional justice scholars and experts, in such situations it is necessary to create conditions that would facilitate the long process of reconciliation.

The historical roots of transitional justice can be traced back to the Nuremberg trials, and even earlier. Yet, the expression of transitional justice was not inserted into the contemporary political lexicon all until the early times of the post-Cold War. (Freeman $2007,7)$ However, the concept got its full significance only at the end of the Cold war in the view of the vast number of bloody intra-state conflicts. Hence, from a perspective of the UN, transitional justice is the full range of processes and mechanisms associated with a society's attempt to come to terms with a legacy of large-scale past abuses, in order to ensure accountability, serve justice and achieve reconciliation (UN 2010, 2). According to the International Center for Transitional Justice (ICTY), transitional justice refers to the set of judicial and non-judicial measures that have been implemented by different countries in order to redress the legacies of massive human rights abuses. These measures include criminal prosecutions, truth commissions, reparations programs, and various kinds of institutional reforms. The extents to which these measures are realistically feasible are always determined by the objective context in the respective societies as well as to some subjective factors, such as the genuine devotion to the idea of reconciliation.

Retributive justice is a theory of justice that considers punishment, if proportionate, is a morally acceptable response to crime, by providing satisfaction and psychological benefits to the victim, the offender and society. Restorative justice is an approach to justice that focuses on the needs of victims and offenders, instead of the need

transitions towards democracy in Southern Europe during the 70s, in Latin America during the 80s and in Eastern and Central Europe in the 90s. The same applies to the post-conflict transitions in Guatemala, Sierra Leone, and the countries of former Yugoslavia.

${ }^{2}$ The literature from this field uses simultaneously the terms "violation" and "abuse as synonyms. The same has been done in this paper as well. 
to satisfy the rules of law or the need of the community to give out punishments. Victims are given an active role in a dispute and offenders are encouraged to take responsibility for their actions, "to repair the harm they have done - by apologizing, returning stolen money, or (for example) doing community service". Restorative justice is based on a theory of justice that focuses on crime and wrong doing as acted against the individual or community rather than authorities. Restorative is usually practiced not only as an equal element of transitional justice (in addition to the retributive justice) but also as a more important one. In addition to addressing the mass violation of human rights, another ground for transitional justice is the need for a holistic approach in its application which implies "combination of telling the truth, criminal charges, remembering, reparation and institutional reforms; this, indicates that the various strategies of facing the past are interconnected." (Simpson, Hodžić and Bickford 2012, 10).

"Although transitional contexts evoke a broad spectrum of moral, legal, and political dilemmas, the challenge of facing the past is inevitable. This is because in these contexts, the pursuit of justice is most frequently a top priority, but capabilities to reach the justice are typically at, or near the bottom - either because of the insufficient capacities and political will, or because of a combination of these factors." (Freeman ibid.) This is one of the contradictions of the post-conflict period or the period of transition: on the one side, there is a need to repair the damage caused by the conflicts, to overcome the harm and suffering by the victims and to restore the peace and harmony between the conflicts sides; but on the other side, vulnerability of the post-conflict situations and suffered human and material losses slow down the process and the willingness to achieve the transitional justice, which, in pursuit to the material and formal truth is faced with internal discrepancies.

\section{The Concept of Transitional Justice}

In this part of this paper the question of defining the concept of transitional justice is addressed. The basic premise is that it is a relatively new and insufficiently known concept both in the public and academic community in the Republic of Macedonia. Interestingly, the term itself evokes certain dilemmas. The efforts to study this concept as 
an academic discipline or a research subject, ${ }^{3}$ at least when it comes to the Macedonian higher education system are apparently at their very beginnings.

A logical sequence would call for defining the concept as universal, and a basic point of reference should be the corresponding international acts. Hence, primarily we take into consideration the UN document on transitional justice from March 2010 - "Guidance Note of the Secretary General: United Nations Approach to Transitional Justice". In this document transitional justice is considered an integral part of the UN framework for strengthening rule of law. It is also emphasized that the UN Charter represents the normative base for promotion of transitional justice along with the four pillars of the contemporary international legal system: international human rights law, international humanitarian law, international criminal law and international refugee law. In this document issued by the Secretary General, transitional justice is defined through its constitutive elements: judicial and non-judicial processes and mechanisms including prosecution initiatives, the truth-seeking, reparation programs, institutional reforms, or appropriate combinations of some of the elements mentioned above. Regardless of the chosen combination, it must correspond to international legal standards and duties. The Secretary General also points out to many other significant issues that have to be embraced by transitional justice. It reflects the necessity of a holistic approach to its application. Namely, transitional justice requires the roots of a conflict to be taken into account, and refers to the violation of all rights, including civil, political, economic, social and cultural rights. ${ }^{4}$ In its effort to address a vast spectrum of violation of the rights in an integrative and independent manner, transitional justice can contribute to the achievement of broader goals of prevention of future conflicts, peace-making, and reconciliation. These goals actually point to the complexity of the demands put in front of the transitional justice. They confirm that transitional justice is not reducible only to retributive justice (i.e. only to penalization) and, in our opinion, they are considered as mission of transitional justice. The UN document invokes various instruments to establish rights and duties related to the

\footnotetext{
${ }^{3} \mathrm{~A}$ good example in this sense is the new study program Criminology and criminal policy at the Faculty of Security in Skopje that includes a syllabus on the transitional justice. Another example is the curriculum of the Institute for Security, Defense and Peace Studies at the Faculty of Philosophy in Skopje, which also includes such a syllabus.

${ }^{4}$ Obviously transitional justice refers to a much broader list of human rights that goes beyond crimes against humanity, genocide and war crimes, determined by the International Criminal Court). In other words, it refers to domains of human lives in cases when human rights are massively violated.
} 
right to law, the right to the truth, the right to reparation and the guarantee of nonrecurrences of violations (duty of prevention). Furthermore it states that the processes of transitional justice should provide that states involved conduct investigations and prosecutions for mass violations of human rights and serious violation of international humanitarian law include also sexual violence.

When it comes to the scholars who put efforts to define the concept of transitional justice, for illustration, we refer to several with no intention to give a comprehensive overview of theoretical literature. The approach of Freeman (ibid.) is interesting both from a point of view of defining and classifying transitional justice. According to him, transitional justice is a new discipline in the framework of the broader domain of human rights. Although he does not elaborate this approach in more detail, one can still sense that he calls for further development of what he calls a "new discipline". He does not argue about its independence in relation to other disciplines concerned with issues of human rights. Other authors talk about several aspects in the studying of the transitional justice within already established scientific disciplines. "Even though it is focused on the global rule of the law, transitional justice became an interdisciplinary field which embraces: criminology, international law, sociology, anthropology, psychology, and public health, related to the intersection of democratization, protection of human rights, and reconstruction of the country after the conflict" (McEvoy, 2007: 412). The interest of the different disciplines discloses competitive perspectives (each from its aspect and its subject of interest) related to strategies for suppressing escalation of violence, healing i.e. recovery of victims, and achieving social peace, as well as the will to embrace them in global discourse (cited according to Humphrey 2010, 12).

Transitional justice is focused on the challenges of societies in transition regardless of whether they transit from war into peace or from authoritarian power into democracy - when they are required to manage the legacy of mass violation of human rights. Transitional justice as a discipline can also be applied in other contexts, including situations when countries with a long tradition of respect of the rule of law face the temporally distant heritage of committed crimes (Freeman ibid.). This means that transitional justice has universal applicative value.

According to another activist and journalist approach, "transitional justice, an area which studies the ways of proceeding past violations of human rights in societies in transition, is one of the most important instruments of the process of democratization led by the international organizations, because it may work as an efficient catalyst of the post- 
conflict reconciliation and stabilization." (Balkanska tranziciona pravda 2012). ${ }^{5}$ This definition emphasizes the leading role of the international organizations, which is disputable having in mind that many definitions of the transitional justice insist it has to be conducted by the respective states and their institutions and other subjects as the only way to achieve reconciliation and enduring peace. Yet, in the quoted definition it is very important that it sees transitional justice as "one of the most important instruments of the process of democratization" and as "an efficient catalyst of the post-conflict reconciliation and stabilization."

Transitional justice is not a particular type of justice but an approach for achieving justice in times of transition from conflicts and/or countries in repression. This is an attempt at achieving responsibility and recompense for victims, where transitional justice helps in recognizing of the rights of victims, promotion of the truth created by the civil sector and strengthening of the democratic rule of law. Transitional justice refers to a set of judicial and non-judicial measures implemented in various countries with the aim of recompense of damage from the heritage of the mass abuse of human rights.

From what we have said so far, it is logical to ask: which societies need transitional justice, and what are their main characteristics? One can conclude that these are societies in which there was a mass and systematic violation of human rights caused in wars/conflicts or totalitarian systems. In this context, the question arises whether the application of traditional justice represents an appropriate "purification" or "aeration" of the system of justice, i.e. does it imply a need for radical changes in the entire system? In the post-conflict period, the state bears responsibility to thoroughly reform its institutions because in the past they were directly involved in mass violations of human rights or were incapable to prevent them. They are expected to provide guarantees for respect of human rights in the future i.e. to prevent any reoccurrence of new wave of abuse in the future. In this context is also the question about the elements of transitional justice. Systematic violations of the human rights have an impact on the immediate victims, and also on the society as a whole. In response to these responsibilities, the task of the state is to guarantee that violations will not be repeated and thus there is a special responsibility in reforming institutions which were either involved or incapable to prevent from abuses.

\footnotetext{
${ }^{5}$ http://www.balkaninsight.com/rs/balkanska-tranziciona-pravda/sta-je-tranziciona-pravda (accsessed on 6 December 2015)
} 
Goals of transitional justice: Hartmann (2012) offers an all-embracing definition of the goals of traditional justice. According to her, traditional justice, in addition to criminal prosecutions, reparation, obstruction of impunity and promotion of the law, also includes goals which refer to the truth-telling, peace-making, promotion of the culture of respect of human rights and democracy, preserving the memory of the victim and restoring of the dignity of the victim. All of these represent preconditions for reconciliation.

Obviously, the main goal of the transitional justice is directed towards sustainable peace. It is also a means that helps in the democratization process through the healing of the society and reconciliation.

Approaches to the transitional justice: According to Michael Humphrey (ibid., 12), possible approaches to the traditional justice are as follows: a way of ceasing the violence and consolidation of peace; an expression of consensus of the type "never more" ${ }^{6}$ in the sense of prevention and criminal processing of crimes against humanity; an expression of the rights which go through the process of globalization, as well as its implications in the restoring of the rule of law and the political legitimacy in a post-conflict country.

According to him, transitional justice refers to a sequence of judicial and nonjudicial procedures regarding crimes against humanity which came about as a result of an internal political conflict; further, he points out that transitional justice is established as a standard approach in the management of political transitions in democracy which applies comparative studying of lessons by borrowing models, as well as real engagement of practitioners and professionals from other countries who survived the conflicts; the term transitional justice also refers to approaches to the responsibility of the state and giving recognition and compensation to victims during the political transition towards democracy, with the aim of terminating the conflict (ibid., 11).

Teitel (cited by Humphrey, ibid.) describes traditional justice as a discourse directed towards "preserving of the minimal level of the rule of law which is identified by peace." This definition is essential for what have already been said about the transitional justice.

As last, one has to pay attention to the definition of traditional justice on the part of several authors (such as Teitel, 2000; Kritz, 1995; Elster, 2004; Roht-Arriaza \& Mariecurrena, 2006 - quoted by Humphrey, ibid., 11), who independently point out that it

\footnotetext{
${ }^{6}$ Project "Never more" is rather novel. It is a historical attempt to prevent brutality and it is focused on protection of the victims of severe violations of human rights. The global policy of human rights is based on a wider international consensus for obstruction of crime as an "indisputable evil" (Meister, 2005: 1 cit. according to Humphrey 2010, 16
} 
refers to series of judicial and non-judicial strategies directed towards rehabilitation of divided societies through acceptance of responsibility about the rule of law and restoration of the legitimacy of the authority and administration in the state.

\section{Elements of transitional justice}

According to the International Center for Transitional Justice, the procedures of transitional justice imply:

- calling the violators of human rights in the past to account through criminal charges and extra-judicial forms of investigation (such as the mechanisms for establishing of truth);

- reparation of victims and efforts for satisfaction of their needs;

- transformation of the system of security so that it can respond to violation of human rights in the past and potential elimination of the violators of human rights from the public institutions; and

- reforms of the public institutions (together with the previous point, they are institutional reforms) in order to prevent repetition of violation of human rights in the past.

Accordingly, transitional justice embraces a wide spectrum of mechanisms for seeking the truth such as initiatives for investigation, commissions and centers for education. Thus, transitional justice moves away from the previous violation of human rights and traces the way towards stable and democratic regimes based on the rule of law. We think that the last should also be observed as an element of transitional justice, which is supported by the defining of the elements of the all-embracing policy of transitional justice in which framework the fifth element is related to the Commissions for truth or other models of research and reporting on systematic patterns of abuse.

The UN document on the approach towards transitional justice defines the following components of transitional justice: judicial and non-judicial processes and mechanisms including prosecution initiatives, facilitating initiatives in the respect of the right to the truth, delivery of reparations, institutional reforms and national consultations (see the Summary of the document, point B). 


\section{Securiaty}

\section{A Short Review of the Difficulties in the Application of Transitional Justice}

Some of the generators of the crisis which hinder the development in the transitional countries during the post-conflict period and thus limit capacity of establishing justice are the following ones: acute congestion of the courts by thousands cases that involve a big number of both victims and perpetrators, and lack of objective capacity for proceeding; the dysfunctional justice system (e.g. corruptness of the police, the prosecutors, and the courts); increase of crime rate, which disperse the judiciary's capacities i.e. disengage them from the cases that derive from the conflict past; also, there are legal obstacles of justice in terms of amnesty laws, obsolescence, expiry of deadlines for complaining, or other incompleteness of the legal system, which is an obstacle in the processing of certain categories of perpetrators. Furthermore, one should add poverty, which takes on an endemic proportion in these countries.

From the said, one can point out at least three immediate consequences, which are also "an intellectual and operational starting point of transitional justice." (Freeman ibid.) One of the potentially positive consequences of this "imperfect" or incomplete justice is the creation of assumptions and space for extra-judicial forms of justice, in less formal forms, which are by default related to the processes of truth-seeking, forgiveness and reconciliation i.e. that are characteristic for restorative justice. This does not imply that restorative justice can substitute for retributive justice but it plays a role of a complementary factor in the post-conflict peace-building.

\section{Several Notes on the Relationship between Restorative and Retributive Justice}

Through the definitions, identification of the integral parts and the relationship between restorative and retributive justice, we aimed to elaborate the transitional justice. We also aim to confirm the thesis that transitional justice has a broader spectrum of goals than the "regular" justice. It is a more complex concept and cannot be reduced to criminal charges and trials. It corresponds to the nature of the societies in transition and the requirements put in front of them, such as: satisfaction of victims, active role of all actors in the restoration process (the perpetrator, the victim, and the community), reforming of the institutions and the system as a whole, and finally - the demand for reconciliation as a precondition of the final goal - establishment of enduring peace, which require complex and long-term activities. 
One of the main theoretical and practical problems refers to the relation between retributive and restorative justice in the context of the application of transitional justice. In this context, the scholars identify at least two dilemmas. The first one is related to the possibility to unite the both approaches. In this regard we invoke to Kesic's thesis according to which: the problem of combining the two models successfully on the territory of former Yugoslavia remains; ${ }^{7}$ one does not know how to proceed with the restorative justice, truthseeking and reconciliation along with the ongoing court processes. The problem is serious, because so far there is no place in the world where two models of justice function simultaneously in a successful way (Kesic 2002, 20). Although the last point may be under dispute, without putting into question the meaning and the inevitability of retributive justice, we argue that restorative justice, by its nature and features, as well as by its conception and philosophy, is more useful in the determination of facts, achievement of understanding, apology, forgiveness, and in the end - reconciliation.

Another dilemma which is pointed out when it comes to the relation between retributive and restorative justice reads: if for any cases there is a trail before court (regardless if the court is ad hoc or regular, domestic or national) then how is it possible to apply amnesty on other cases that have same or similar essence? How to facilitate the achievement of recognition or the discovery of the truth, and thus pave the way to the process of reconciliation? Kesic (ibid.) rightly argues: "The key question is: can crimes be processed only to a certain level and then to introduce amnesty in exchange for recognition and discovering of the truth? This would call into question the universal aspect of justice. Further, the situation in former Yugoslavia is specific because the most truth and reconciliation commissions deal internally inside only one state and its society, with a final goal of restoration of the broader social community and the local ones, and also in order to overcome deep societal divisions and to face one's own traumatic past.... The challenge for the politicians and the legal experts is huge, as well for us, the participants and the actors of the civil society; yet it is worthwhile facing."

\footnotetext{
${ }^{7}$ Although the article focuses on the situation in the countries of former Yugoslavia, in our opinion this question is relevant for other post-conflict societies as well.
} 


\section{Conclusion}

At the end, we can conclude that in the practice so far retributive justice (which is mostly achieved by court trials) has been dominant approach over restorative justice. Also, in the process of implementation, the external factor (i.e. international institutions and organizations) have often been more involved than the national subjects. This practice has surely some exceptions, such as Croatia and Kosovo where international factor has far greater impact than in Serbia. In general, there is an impression that justice was "external", and even "imposed". The practice that external factors solve local conflicts or problems in general, or so to say, serve as mediators, is still ongoing, even two and half decades after the independence of the former Yugoslav republics. On the other hand, there is the question of whether the declarative pledge that retributive justice should be supplemented by the processes and mechanisms of restorative justice, has been really supported. In fact, the criticisms directed towards the EU when it comes to the pledge, and even more the implementation, i.e. non-implementation of the restorative justice as a significant segment of transitional justice, and even the lack of a strategy for it, is sufficiently indicative. The study entitled "European Union and transitional justice: from retributive to restorative justice in Western Balkan" is especially critically oriented with regard to the role of the EU in the affirmation, promotion and support of the restorative justice in the post-conflict and transitional societies, by the claim of certain authors in the study that the EU does not have a strategy related to this issue and does not know how to apply the real opportunity and the good sides of the restoration and the related transitional justice (it reduces it to only one of its segments - the retribution), as well as the potentials and the capacities of the civil sector of these societies (Kostovicova 2007). "Trials in Hague and in future national courts ${ }^{8}$ should lead towards "a new beginning", where we do not refer to a reconstruction of the old state, but a reconstruction of the universal human unity. And the possibility of a new beginning is, as Hannah Arendt says in the last pages of The origins of totalitarianism, the biggest human ability. From political aspect, this possibility is identical with human freedom" (Kesic ibid., 20).

\footnotetext{
${ }^{8}$ National courts (or their departments) in the meantime (since the work we refer to was written) started working on such trails, but not in all states. Macedonia is among the ones where such courts have not been formed yet.
} 


\section{Securitity}

\section{Bibliography}

1. Freeman, M. (2007), "What is transitional justice?", in: Marijana Toma (ed.), Forum za tranzicionu pravdu, Belgrade: FHP

2. Guidance note of the Secretary General: United Nations Approach to Transitional Justice, UN: March 2010

3. Hamber B. (2004) Coming to terms with the conflict in and about Northern Ireland:Lessons from the Healing Through Remembring Project, Temida, no. 4

4. Hartmann F. (2012), "The role and duty of the media in the process of postwar reconciliation" in: Denisa Kostovicova (ed.), Transitional justice in the post-Yugoslavian countries: Political will and support in the public in the process of REKOM, Forum for transitional justice, Belgrade

5. Humphrey M. (2010) "Policy of trauma and reconciliation", Temida, vol. 13. no. 1.

6. Kesić V. (2002) Truth and reconciliation - Yes, please! No, thank you! Temida, March 2002

7. Kostovicova D. (ed.), Transitional justice in the post-Yugoslavian Countries: Political Will and Support in the Public in the process of REKOM, Forum for transitional justice, Belgrade

8. Kostovicova D. (ed.) (2007), European Union and transitional justice: from retributive to restorative justice, Belgrade: FHP

9. McEvoy K. (2007), "Beyond Legalism: Towards a Thicker Understanding of Transitional Justice", Journal of Law and Society, vol. 34, no. 4.

10. Nikolić-Ristanović V. and J. Srna (2010) "Reconciliation with oneself and with others: From approach to model", Temida, vol.13, no. 1.

11. Parmentier S.,Valinas M. and Elmar Weitekamp, (2010) Re-establishment of justice in Serbia - Reconciliation and restorative justice in a post-conflict context, Temida, vol. 13, no. 1.

12. Petrović, M. N., (2010) Researches on the most adequate forms of remembering the past and models of establishing trust on the territory of former Yugoslavia, Temida, vol. 13, no. 1. 


\section{Securiaty}

13. Puljek - Shank, A. (2007), "Trauma and Reconciliation in the compilation: Towards reconciliation". In: Helena Rill, Tamara Smidling and Ana Bitoljanu (eds.), 20 Pieces of Encouragement for Awakening and Change. Peacebuilding in the Region of the Former Yugoslavia. Available at:

http://www.nenasilje.org/publikacije/pdf/20poticaja/20pieces-eng.pdf (accessed on 1 December 2015)

14. Simpson, G., E. Hodžić and L. Bickford, (2012), Looking Back, Looking Forward: Promotion Dialogue through Truth Seeking in Bosnia and Herzegovina, UNDP, Switzerland 